\title{
The Effect of a Mixed-Starter Culture of Lactic Acid Bacteria on the Characteristics of Pickled Orange-Fleshed Sweet Potato (Ipomoea batatas L.)
}

\author{
NETI YULIANA*, SITI NURDJANAH, AND MIKA MARGARETA \\ Department of Agricultural Product Technology (THP), Agriculture Faculty, Universitas Lampung, Jalan Sumantri \\ Brojonegoro No 1, Bandar Lampung 35145, Indonesia
}

\begin{abstract}
In this study, fermentation process was carried out on orange-fleshed sweet potato cubes to produce sweet potato pickle using a mixed culture of Lactobacillus plantarum and Leuconostoc mesenteroides at $30^{\circ} \mathrm{C}$ over $12 \mathrm{~d}$ period. Spontaneous fermentation was also performed as a control. Samples were withdrawn at various time intervals for analyses of reducing sugar content, total number of lactic acid and non-lactic acid bacteria, lactic acid concentration, $\mathrm{pH}$, and sensory attributes. The results showed that using a mixed culture of $L$. plantarum and L. mesenteroides could greatly reduce contamination of non-lactic acid bacteria, retaining low amount of reducing sugar, rapidly producing lactic acid and consequently decreasing $\mathrm{pH}$ value of the pickle, as well as giving better sensory score. After $12 \mathrm{~d}$ of fermentation, sample of pickle inoculated with mixed culture showed the following characters: total lactic acid content $0.5 \%$, total lactic acid bacteria $8.46 \log _{10} \mathrm{CFU} \mathrm{mL} L^{-1}$, total non-

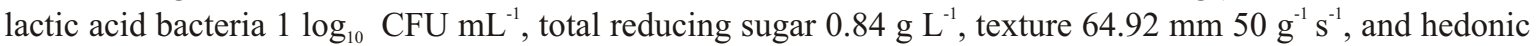
sensory score for both taste and aroma 4 (like) in a scale of 5 . These results indicated the potential ability of the mixed culture of lactic acid bacteria to improve the quality of the pickle fermented spontaneously.
\end{abstract}

Key words: fermentation, lactic acid bacteria, mixed-starter cultures, pickle, sweet potato

Pada penelitian ini, potongan ubi jalar kuning difermentasi untuk memproduksi pikel menggunakan kultur campuran Lactobacillus plantarum dan Leuconostoc mesenteroides pada $30{ }^{\circ} \mathrm{C}$ selama 12 hari. Fermentasi spontan juga dilakukan sebagai kontrol. Parameter yang diamati meliputi gula reduksi akhir, total bakteri asam laktat (BAL), total non-BAL, konsentrasi asam laktat, $\mathrm{pH}$, tekstur, dan sensori. Hasil penelitian menunjukkan bahwa pengunaan kultur campuran $L$. plantarum dan L. mesenteroides dapat menekan pertumbuhan kontaminan non-BAL, menyisakan sejumlah kecil gula reduksi, menghasilkan asam laktat dengan cepat sehingga menurunkan $\mathrm{pH}$ secara cepat, serta menghasilkan sensori yang lebih baik. Karakteristik pikel setelah 12 hari fermentasi adalah sebagai berikut: total asam laktat $0,5 \%$, total BAL $8,46 \log _{10} \mathrm{CFU} \mathrm{mL}{ }^{-1}$, total non-BAL 1

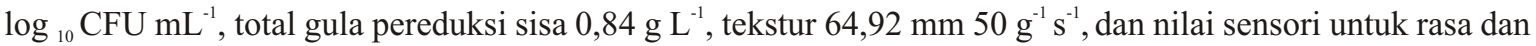
aroma masing masing adalah 4 (suka) dari 5 skala, untuk pikel dengan perlakuan kultur campuran. Hasil ini menunjukkan bahwa penggunaan kultur campuran BAL pada fermentasi pikel ubi jalar dapat memperbaiki kualitas pikel yang difermentasi secara spontan.

Kata kunci: bakteri asam laktat, fermentasi, kultur campuran pikel, ubi jalar

Orange fleshed sweet potatoes have important nutritional values because of high concentration of $\beta$ carotene that functions as provitamin A. The carotenoid content of orange-fleshed sweet potatoes has been reported around $18 \mathrm{mg} / 100 \mathrm{~g}$ fresh weight (Panda et al. 2007). This potential character of orangefleshed sweet potatoes should be responded by many food manufacturers to produce a healthy food. An alternative to diversify the sweet potato utilization is to use it as a raw material for pickle processing.

Most pickled vegetables are processed through spontaneous fermentation without inoculum addition. For this reason, the result of the process is often very unpredictable due to the diversities of the initial microflora. This has caused inconsistency in the

*Corresponding author; Phone/Fax: +62-721-781498, Email: yuliana_thp@unila.ac.id quality of the pickle, off-flavoring, and the growth of different types of microorganisms. Fresh vegetables may contain various wild microflora, dominated by non lactic acid bacteria responsible for spoilage (Fleming 1982). An alternative to control the fermentation process is by adding lactic acid bacteria (LAB) cultures during pickle processing. LAB could rapidly produce lactate and other organic acids, and accumulate them in the raw materials. Furthermore, they can also produce various metabolites that contribute to the development of some desirable characteristics such as visual appearance, texture, shelf-life, acceptability, and safety (Holzapfel 1997; Holzapfel 2002; Leroy and Vuyst 2004; Dalie et al. 2010 ). Some researchers have shown potential benefits of using starter cultures in fermentation, for example in the productions of low-salt sauerkraut, sauerkraut, 
sauerkraut juice, and sausages (Tolonen et al. 2002; Wiander and Ryhanen 2005; Johanningsmeier et al. 2007; Rai et al. 2006; Hu et al. 2007).

Research on the production of pickled sweet potatoes has not been done as intensively as on pickled cucumber. Several groups have reported the fermentation of pickled sweet potatoes without inoculation with a mixed culture (Panda et al. 2007; Panda et al. 2009; Sivakumar et al. 2010; Yuliana and Nurdjanah 2009; and Yuliana et al. 2010). So far there is no report mentioning the effect of inoculation with bacterial cultures commonly used for pickle processing, such as Leuconostoc mesenteroides and Lactobacillus plantarum, on the characteristics of pickled sweet potatoes. In this study, we compared the effects of adding $L$. mesenteroides and $L$. plantarum cultures on pickled sweet potatoes to pickle that had been processed spontaneously (without culture addition), to determine whether the addition of these starter cultures might have given positive effects on the fermentation.

\section{MATERIALS AND METHODS}

Preparation of Starter Culture. Pure cultures of L. plantarum FNCC 0123 and L. mesenteroides FNCC 0023 were purchased from Food and Nutrition Inter University Center (PAU) Universitas Gadjah Mada. The starter was prepared by inoculating one loop of pure cultures of $L$. mesenteroides FNCC 0023 and $L$. plantarum $\mathrm{FNCC} 0123$ into tubes containing $10 \mathrm{~mL}$ of sterile MRS Broth and incubated at $37^{\circ} \mathrm{C}$ for $24 \mathrm{~h}$. One $\mathrm{mL}$ of these cultures was then sub cultured twice (using pour plate and streak plate methods) in MRS agar at 37 ${ }^{\circ} \mathrm{C}$ for $24 \mathrm{~h}$. Single colony was picked up and inoculated twice into a centrifuge tube containing 10 $\mathrm{mL}$ MRS broth and incubated for $24 \mathrm{~h} 37^{\circ} \mathrm{C}$ for the first and $48 \mathrm{~h} 37^{\circ} \mathrm{C}$ for the second incubation. Finally, the broth of each culture of $L$. plantarum and $L$. mesenteroides were combined and harvested by centrifugation (IEC Centra CL2 Centrifuge) at $349 x$ $\mathrm{g}$ for $5 \mathrm{~min}$. The amount of cells in this preparation was approximately $2 \times 10^{6} \mathrm{CFU} \mathrm{mL}$.

Brine Solution Preparation. Brine solution was prepared by mixing $15 \mathrm{~g} \mathrm{NaCl}$ with $2.5 \mathrm{~g}$ sucrose, and then dissolved in $250 \mathrm{~mL}$ distilled water. The brine solution were heated using microwave oven (Sharp) at high level setting for $6 \mathrm{~min}$ to achieve $60^{\circ} \mathrm{C}$, and then left for $7 \mathrm{~min}$ in a container containing warm water (35$40{ }^{\circ} \mathrm{C}$ ). This solution was distributed into $150 \mathrm{~mL}$ of fermenting containers.
Sweet Potato Pickle Processing. Orange-fleshed sweet potato samples were obtained from Pasar Gintung, a local market at Bandar Lampung, Province of Lampung-Indonesia. The sweet potatoes were washed, peeled, and cut into cubes $\left(1 \times 1 \times 1 \mathrm{~cm}^{3}\right)$. The potato cubes $(40 \mathrm{~g})$ were put into a $150 \mathrm{~mL}$-fermenting container, then it was made up to $150 \mathrm{~mL}$ volume with the brine solution. The fermenting containers containing the samples were pasteurized using a microwave oven (Sharp) at high level setting for 10 min to reach temperature around $72-73{ }^{\circ} \mathrm{C}$, and then they were left at room temperature to cool. Each sample was inoculated with the mixed culture of $L$. plantarum and L. mesenteroides at level of $2 \times 10^{6} \mathrm{CFU}$ $\mathrm{mL}^{-1}$. In addition, fermenting container without inoculum addition was also prepared as a control. The fermentation was conducted at room temperature (30 ${ }^{\circ} \mathrm{C}$ ) for $12 \mathrm{~d}$. The experiment was designed in four replicates.

Evaluation of the Characteristics of the Pickled Sweet Potatoes. Evaluation on the physicochemical properties was performed on lactic acid by titration method (AOAC 1980), reducing sugar using NelsonSomogyi method (Somogyi 1952), starch, and texture. The starch content was determined enzymatically at the beginning and the final day of fermentation. The sample was homogenized, gelatinized, and subjected to $\alpha$ amylase and amyloglucosidase (Sigma-Aldrich) digestion for $20 \mathrm{~min}$ at $55^{\circ} \mathrm{C}$ then the enzyme activity was stopped by adding few drops of tri chloroacetic acid (TCA) and centrifuged at $1398 \mathrm{xg}$ (slightly modified from Nurdjanah 2008). The glucose in the supernatant was quantified using phenol-sulfuric acid method (Dubois et al. 1956). Total starch content was calculated by multiplying the result by 0.90 (AOAC 1980). Texture was determined according to Nurdjanah et al. (2007) using penetrometer (Precision, Scientific Petroleum Instruments) and reported as the depth of the sweet potato tissue penetrated by the cone probe when applied with $50 \mathrm{~g}$ loading force per second $\left(\mathrm{mm} 50 \mathrm{~g}^{-1} \mathrm{~s}^{-1}\right)$.

Microbial growth during fermentation was evaluated by counting the total lactic acid bacteria (LAB) and non-lactic acid bacteria (non-LAB) using total plate count method. Appropriate dilutions were placed on duplicate plates of MRS agar medium (Oxoid) containing $0.1 \%(\mathrm{w} / \mathrm{v}) \mathrm{CaCO}_{3}$. The cultures were then incubated at $30{ }^{\circ} \mathrm{C}$ for $48 \mathrm{~h}$. LAB was identified by the presence of clear zones around the colonies; otherwise they were identified as non-lactic acid bacteria.

The sensory evaluation was conducted at day 12 of 
fermentation according to method by Meilgaard et al. (2007) and performed by a sensory panel composed of 18 panelists. A five-point hedonic scale, varying from dislike very much (score 1 ) to like very much (score 5) was used. Each of 18 panelists evaluated all samples in randomized order of presentation and evaluated the pickle in relation to taste and aroma using the score sheet for hedonic testing.

\section{RESULTS}

The increase of cell numbers (represented in CFU $\mathrm{mL}^{-1}$ ) produced during $12 \mathrm{~d}$ fermentation with prior inoculation of $L$. plantarum and L. mesenteroides mixed culture is shown in Fig 1A-1B. During $12 \mathrm{~d}$ of fermentation, the populations of these strains increased approximately $5 \log$ cycles, while the number of LAB in control increased only approximately $2 \log$ cycles. The total number of LAB in the spontaneous fermentation was lower than those in batch with mixed inoculum throughout the $12 \mathrm{~d}$ of fermentation.

The lactic acid was already observed at early stage of fermentation and rapidly increased to an amount of $0.3 \%$ $(\mathrm{v} / \mathrm{v})$ on day three of fermentation in batch with mixed inoculum. However, inspontaneous fermentation, rapid increase was observed on day six of fermentation (Fig 2A). Lactic acid content increased linearly with fermentation time from 0.03 to $0.27 \%$ and 0.007 to $0.52 \%$ at rate 0.06 and $0.11 \%$ for $12 \mathrm{~d}$ in spontaneous and mixed inoculum batch, respectively. The final lactic acid content of the pickle inoculated with mixed culture and spontaneous fermentation was 0.52 and $0.27 \%$, respectively.

The reducing sugar increased quadratically with fermentation time from 0.46 to 0.71 and 0.44 to $0.84 \mathrm{~g}$ $\mathrm{L}^{-1}$ in both spontaneous and mixed inoculum pickle, respectively, during $12 \mathrm{~d}$ fermentation (Fig 2B).

In contrast to the patterns observed on reducing sugar and starch utilization, during $12 \mathrm{~d}$ of fermentation the texture of the pickles seemed to alter
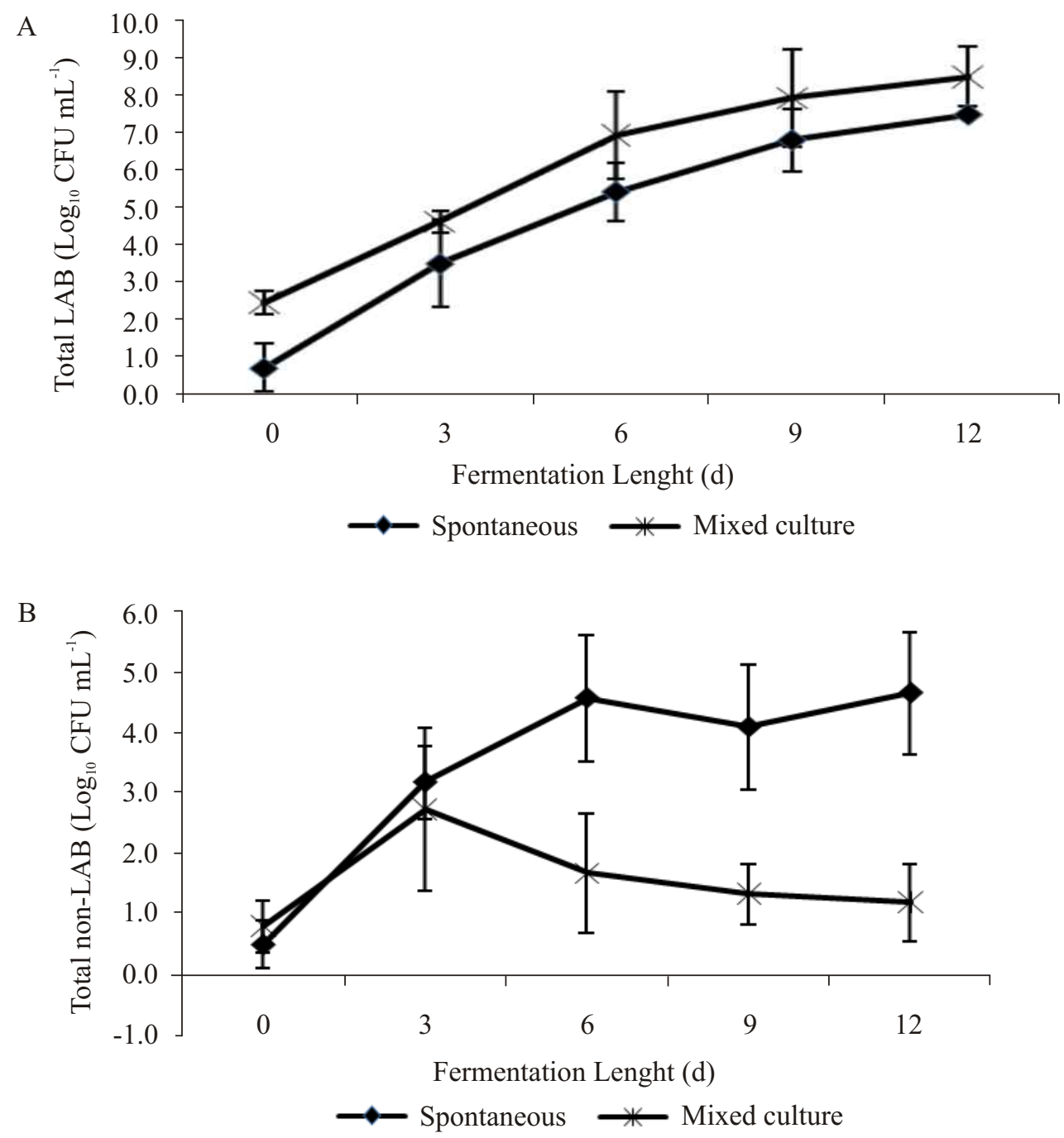

Fig 1 Total LAB (A) and non-LAB (B) population during $12 \mathrm{~d}$ fermentation. 

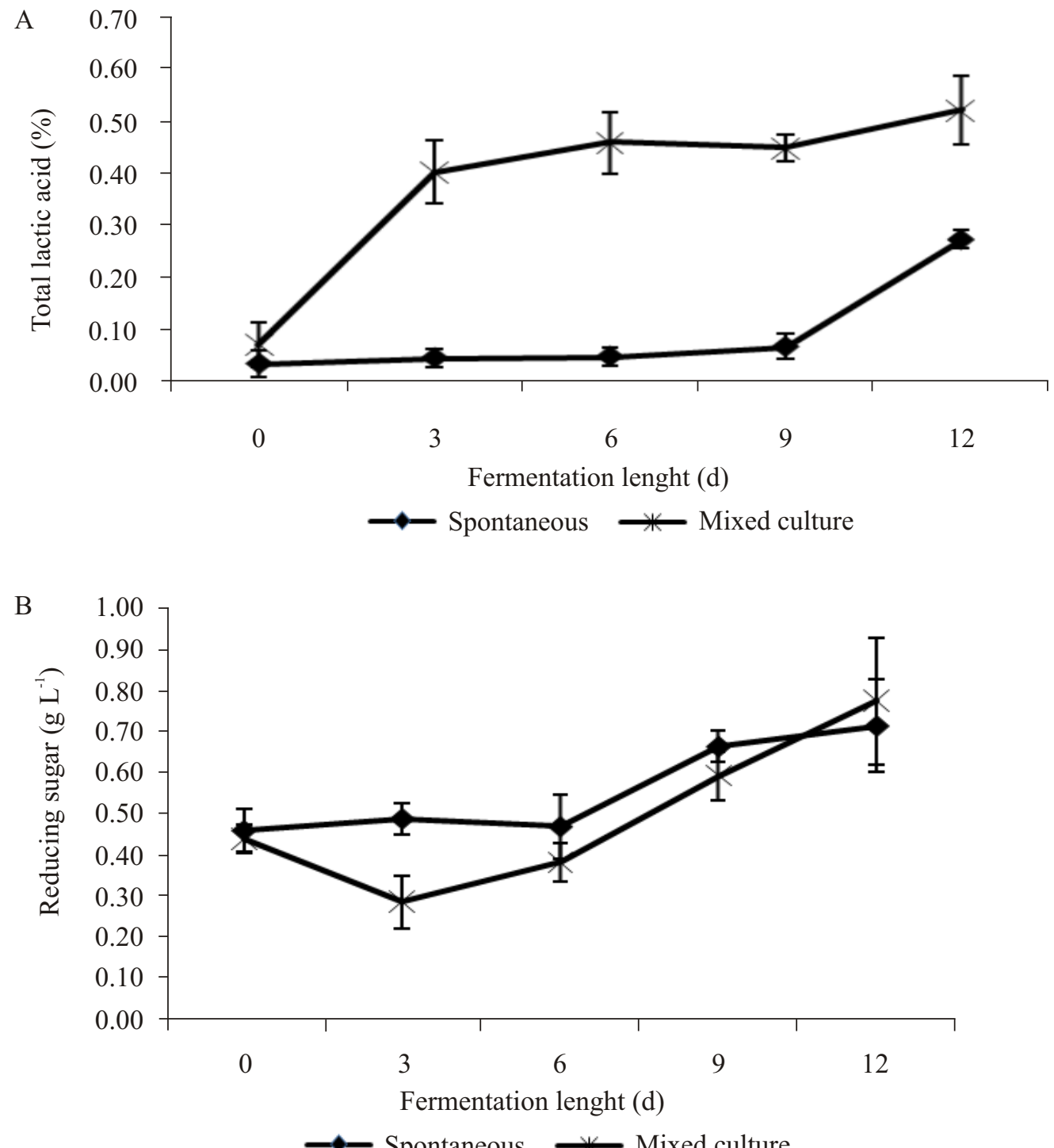

Fig 2 Total lactic acid (A) and reducing sugar (B) production during $12 \mathrm{~d}$ fermentation.

in similar pattern, whether inoculated with mixed culture or not (Fig 3). The firmness of the pickled vegetable decreased quadratically with fermentation time, as indicated by the increasing depth the probe could penetrate the tissue, that is from 43.16 to 59.31 in

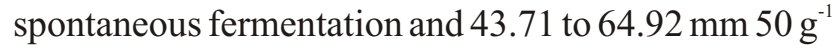
$\mathrm{s}^{-1}$ in pickled that had been inoculated with mixed culture.The final texture of pickle with mixed culture

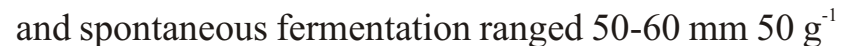
$\mathrm{s}^{-1}$, indicating that the texture of the pickle cube was slightly softer.

The sensory evaluation showed that panelists prefered the pickle that had been inoculated withmixed culture. The scores for taste and aroma of the pickle inoculated with mixed culture were 3.9 and 4.2 (liked), while scores of those with spontaneous fermentation

Table 1 The starch content of fresh and pickled sweet potato

\begin{tabular}{lccc}
\hline \multirow{2}{*}{\multicolumn{1}{c}{ Treatments }} & \multicolumn{3}{c}{ Starch content (\%) } \\
\cline { 2 - 4 } & $\begin{array}{c}\text { Before } \\
\text { fermentation }\end{array}$ & $\begin{array}{c}\text { After } \\
\text { fermentation }\end{array}$ & Efficiency (\%) \\
\hline Fresh sweet potato* & $29.11 \pm 1.11$ & - & - \\
Spontaneous & $29.33 \pm 1.07$ & $25.43 \pm 0.09$ & 13.30 \\
Inocultaed with mixed culture & $26.84 \pm 0.31$ & $21.06 \pm 1.91$ & 21.57 \\
\hline *moisture content of fresh sweet potato was $81 \%$ & &
\end{tabular}




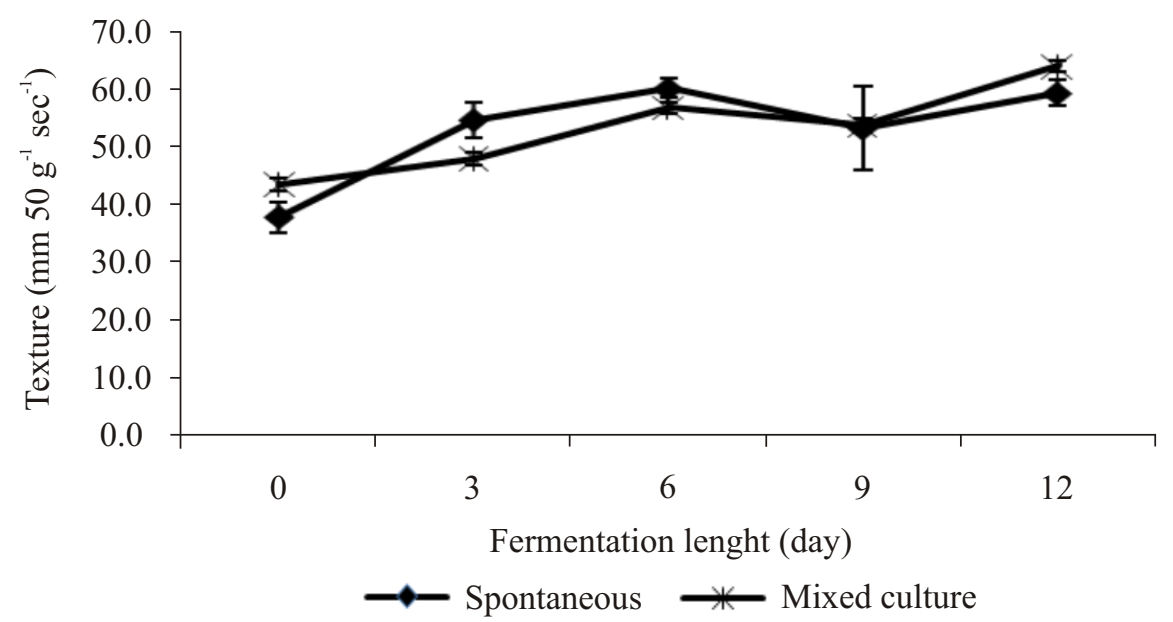

Fig 3 Change of texture during $12 \mathrm{~d}$ fermentation.

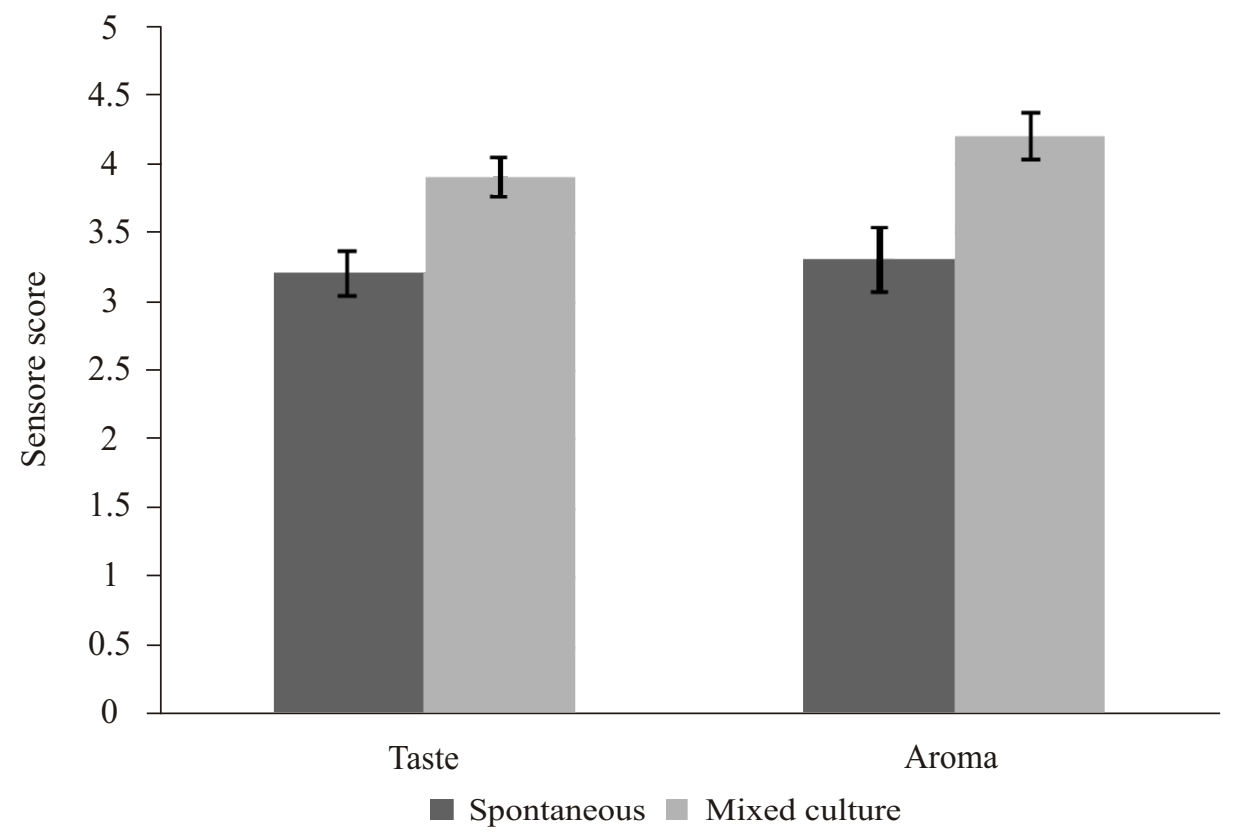

Fig 4 Hedonic sensory score at day 12 fermentation of pickle with spontaneus fermentation and mixed culture inoculation. Score $1=$ dislike very much, 2 = dislike, 3 = moderate (neither like nor dislike), 4 =like, 5 =like very much.

were 3.2 and 3.3 (neither liked nor disliked).

\section{DISCUSSION}

The addition of LAB culture significantly affected the total $\mathrm{LAB}$, total non-LAB, lactic acid content, and reducing sugar during fermentation, as well as the sensory of final product. Throughout the $12 \mathrm{~d}$ of fermentation the total population of LAB in the spontaneous fermentation was lower than those in batch inoculated with mixed culture. The higher population of LAB in the pickle that had been inoculated with mixed culture greatly reduced the total contaminating non-LAB. Consequently, the population of total non-LAB in the batch with spontaneous fermentation was higher than those in the batch that was inoculated with mixed cultures (Fig $1 \mathrm{~B}$ ). The high population of $\mathrm{LAB}$ at the initial stage of fermentation had an important role in inhibiting growth of contaminants even after fermentation had started ( $\mathrm{Hu}$ et al. 2007; Rai et al. 2006). In order to control the fermentation, LAB starter cultures have been used in the fermentations of sauerkraut, olives, cucumber, sausages, and other fermented products (Fleming et al. 2001; Hu et al. 2007; Rai et al. 2006; Zdolec et al. 2008). The different LAB population densities could affect the amount of lactic acid produced. It has been found that the faster the production of lactic acid, the faster the $\mathrm{pH}$ decreased (Tolonen et al. 2002; Wiander and Ryhanen 2005), thus the faster the completion of 
fermentation.

Reducing sugar remained relatively lower in the culture inoculated batch than that in spontaneous batch throughout the fermentation. This was probably due to a faster growth rate of starter culture. LAB produced amylase enzyme which rapidly degraded starch to simple sugars thatcould then be utilized for lactic acid production (Petrova et al. 2013). Therefore, rapid decrease of reducing sugar in substrate (Fig 2B) was observed in the LAB culture inoculated batch. The degradation of starch was indicated by the decrease of starch content in the pickled sweet potatoes after fermentation (Table 1). Amylase enzyme was reported to present naturally in sweet potatoes (Takahata et al. 1995; Hagenimana et al. 1994; Krishnan et al. 2010) and produced by LAB as well (Reddy et al. 2008; Petrova et al. 2013 ). This enzyme was able to rapidly degrade starch to a simple sugar such as glucose.

After day 12, the texture of the culture inoculated and spontaneously fermented pickled potatoes were both slightly soft. It has been documented that the texture is influenced by the main components of plant cell wall polysaccharides, such as cellulose, pectin, and matrix polysaccharides that are composed of interconnected hemicelluloses bound to cellulose microfibrils (Imam et al. 2005). This structural components give the cell wall its rigidity. It is assumed that enzymes produced by LAB and non-LAB during fermentation along with the enzymes present in the sweet potatoes were to be the major contributors to this cell wall degradation and caused the disruption of the texture of the sweet potatoes pickle.

Lactic acid bacteria and other microbes are able to produce depolymerizing enzymes that act on cell-wall components (Marin-Rodriguez et al. 2000; Mokemiabeka et al. 2011) and on starch (Petrova et al. 2013), thus destroying the integrity of the plant tissues. Enzymatic tissue softening caused by microbial agents has been reported in pickled cucumber (Maruvada and McFeeters 2009) and other fruits and vegetables containing pectin (Duvetter et al. 2009). However, the depolymerizing enzymes contributing to the softening of the pickle might have come from the sweet potatoes. It has been found that pectin esterase, pectin methyl esterase (PME), $\alpha$ and $\beta$ amilase were natural enzymes present in sweet potatoes (Sunmola and Bukoye 2011; Binner et al. 2000; Hagenimana et al.1994; Ikemiya and Deobald 1966). However, the activity of PME could be inhibited by rapid $\mathrm{pH}$ reduction (Turk 1989). This might be the rational reason why the slight softening was observed in both batch fermentations.
The addition of LAB caused a rapid acid accumulation in the raw material, with the production of lactic and several organic acids as well as other various metabolites. Furthermore, the presence of LAB culture could suppress the total non-LAB contaminants contributing to off-flavor of the pickle. Consequently, a inoculating the pickle with mixed LAB culture helped to develop good sensory properties on the aroma and the tastes. The benefits of LAB culture addition have been reported by some authors. The mixed cultures containing L. mesenteroides and L. plantarum gave sauerkraut and sauerkraut juice the most desirable sensory characteristics (Wiander and Ryhanen 2005). No significant off-flavor was observed on salted cabbage inoculated with $L$. mesenteroides at the end of the fermentation, sauerkraut which had been inoculated with this strain was more uniformly fermented in comparisios to the one produced bys spontaneous fermentations (Johanningsmeier et al. 2007).

In conclusion, the results indicated the positive effect of a mixed culture of $L$. plantarum and $L$. mesenteroides on the safety and sensory quality (aroma, taste, and texture) of pickled orange-fleshed sweet potato. The addition of these LAB cultures significantly suppressed the total of non-LAB as contaminant that could contribute to the off-flavor of the pickle. This finding supported the previous similar studies on fruit and vegetable fermentation.

\section{REFERENCES}

Ampe F, Brauma A. 1995. Origin of enzymes involved in detoxification and root softening during cassava retting. World J Microbiol Biotechnol. 11(2):178-182. doi:10.1007/BF00704644.

AOAC. 1980. Official Methods of Analysis of the Association of Official Analytical Chemist. Arlington, Virginia.

Binner S, Jardine W, Renard C, Jarvis M. 2000. Cell wall modifications during cooking of potatoes and sweet potatoes. J Sci Food and Agric. 80(2):216-218. doi:10.1002/(SICI)1097-0010(20000115)80:2<216::AIDJSFA507>3.0.CO;2-6.

Dalie DKD, Deschamps AM, Richard-Forget F. 2010. Lactic acid bacteria Potential for control of mould growth and mycotoxins: A review. J Food Control. 21(4):370-380. doi:10.1016/j.foodcont.2009.07.011.

Dubois M, Gilles KA, Hamilton JK, Rebers PA, Smith F. 1956. Colorimetric method for determination of sugars and related substances. Anal Chem. 28(3):350-356. doi:10.1021/ac60111a017.

Duvetter T, Sila DN, Van Buggenhout S, Jolie R, Van Loey A, Hendrickx M. 2009. Pectins in processed 
vegetables: Part I-stability and catalytic activity of pectinases. Compr Rev Food Sci Food Saf. 8(2):75-85. doi:10.1111/j.1541-4337.2009.00070.x.

Fleming HP, McFeeters RF. Breidt F. 2001. Fermented and acidified vegetables. In: Downes FP, Ito K, editors. Compendium of Methods for the Microbiological Examination of Foods, 4th ed. Washington DC: American Public Health Association. p 521-532.

Fleming HP. 1982. Fermented vegetables. In: Rose AH, editor. Economic microbiology of fermented foods. New York: Academic Press. p 52-70.

Hagenimana V, Vezina LP, Simard RE. 1994. Sweet potato $\alpha$ - and $\beta$-amylases: characterization and kinetic studies with endogenous inhibitors. J Food Sci. 59(2):373-376. doi:10.1111/j.1365-2621.1994.tb06970.x.

Holzapfel W. 1997. Use of starter cultures in fermentation on a household scale. Food Control. 8(5-6):241-258. doi:10.1016/S0956-7135(97)00017-0.

Holzapfel WH. 2002. Appropriate starter culture technologies for small-scale fermentation in developing countries. Int J Food Microbiol. 75(3): 197-212. doi:10.1016/S0168-1605(01)00707-3.

Hu Y, Xia W Ge C. 2007. Effect of mixed starter cultures fermentation on the characteristics of silver carp sausages. World J Microbiol Biotechnol. 23(7):10211031. doi:10.1007/s11274-006-9330-2.

Ikemiya M, Deobald MH. 1966. New characteristic alphaamylase sweet potatoes. J Agric Food Chem. 14(3): 237-241. doi:10.1021/jf60145a011.

Imam S, Shey J, Wood D, Glenn G, Chiou B, Inglesby M, Ludvik C, Klamczynski A, Orts W. 2005. Structure and function of complex carbohydrates in produce and their degradation process. In: Lamikanra O, Imam S, Ukuku $\mathrm{D}$, editors. Produce degradation-pathways and prevention. Florida:CRC Press. p 563-597.

Johanningsmeier S, McFeeters RF, Fleming HP, Thompson RL. 2007. Effects of Leuconostoc mesenteroides starter culture on fermentation of cabbage with reduced salt concentrations. J Food Sci. 72(5):M166-M172. doi:10.1111/j.1750-3841.2007.00372.x.

Leroy F, Vuyst LD. 2004. Lactic acid bacteria as functional starter cultures for the food fermentation industry. Trends Food Sci Tech. 15(2):67-78. doi:10.1016/j.tifs. 2003.09.004.

Krishnan JG, Padmaja G, Moorthy SN, Suja G, Sajeev MS. 2010. Effect of pre-soaking treatments on the nutritional profile and browning index of sweet potato and yam flours. Innov Food Sci Emerg Technol. 11(2): 387-393. doi:10.1016/j.ifset.2010.01.010.

Marin-Rodriguez MC, Orchard J, Seymour GB. 2002. Pectate lyases, cell wall degradation and fruit softening. Fruit development and ripening special issue. J Exp Bot. 53(377):2115-2119. doi:10.1093/jxb/erf089.

Maruvada R, McFeeters RF. 2009. Evaluation of enzymatic and non-enzymatic softening in low salt cucumber fermentations. Int J Food Sci Technol. 44(6): 1108-1117. doi: 10.1111/j.1365-2621.2009.01925.x

Meilgaard D, Civile GV, Carr BT. 2007. Sensory evaluation techniques ( $4^{\text {th }}$ edition). Florida:CRC Press.
Mokemiabeka S, Dhellot J, Kobawila SC, Diakabana P, Ntietie-Loukombo RN, Nyanga-Koumou AG, Louembe D. 2011. Softening and mineral content of cassava (Manihot esculenta Crantz) leaves during the fermentation to produce Ntoba mbodi. Adv J Food Sci and Technol. 3(6):418-423.

Nurdjanah S, Susilawati, Sabatini MR. 2007. Prediksi kadar pati ubi kayu (Manihot esculenta) pada berbagai umur panen menggunakan penetrometer. [Prediction of starch content on cassava at various levels of harvesting day, using penetrometer]. J Teknologi \& Industri Hasil Pertanian. 12(2):66-74.

Nurdjanah S. 2008. Extraction and characterisation of pectin from Australian and Indonesian sweet potato [thesis]. New South Wales (AU): University of New South Wales, Australia.

Panda SH, Parmanick M, Ray RC. 2007. Lactic acid fermentation of sweet potato (Ipomoea batatas L.) into pickles. J Food Process Preserv. 31(1):83-101. doi: 10.1002/9781444319330.

Panda SH, Panda S, Sivakumar PS, Ray RC. 2009. Anthocyanin-rich sweet potato lacto-pickle: Production, nutritional and proximate composition. Int $\mathrm{J}$ Food Sci Technol. 44(3):445-455. doi: 10.1111/j.13652621.2007.01692.x.

Petrova P, Petrov K and Stoyancheva G. 2013. Starchmodifying enzymes of lactic acid bacteria-structures, properties, and applications. Starch/Starke . 65:34-47. doi:10.1002/star.201200192.

Rai KP, Zhang C, Xia W. 2006. The effects of mixed starter cultures on the quality of dry fermented Chinese-style sausages. Trop Agric Res Extension. 9:103-115.

Reddy G, Altaf M, Naveena, BJ, Venkateshwar M, Kumar EV. 2008. Amylolytic bacterial lactic acid fermentation-a review. Biotechnol Adv. 26(1):22-34. doi:10.1016/j.biotechadv.2007.07.004.

Sivakumar PS, Panda S.H, Ray RC, Naskar SK. Bharathi LK. 2010. Consumer acceptance of lactic acid fermented sweet potato pickle. J Sensory Studies. 25(5):706-719. doi:10.1111/j.1745-459X.2010.00299.x.

Somogyi M. 1952. Notes on sugar estimation. J Biol Chem. 195(1):19-23.

Sunmola AI, Bukoye OO. 2011. Biochemical response of sweet potato to bemul-wax coating combined with calcium chloride treatment during ambient storage. African J Biotechnol. 10(14):2724-2732.

Takahata Y, Noda T, Sato T. 1995. Changes in carbohydrate and enzyme activities sweet potato lines during storage. J Agric Food Chem. 43(7):1923-1928. doi: 10.1021/jf00055a031.

Tolonen M, Taipale M, Viander B, Pihlava J-M, Korhonen H, Ryhanen E-L. 2002. Plant-derived biomolecules in fermented cabbage. J Agric Food Chem. 50(23):6798803. doi: 10.1021/jf00055a031.

Turk F. 1989. Characterization of factors affecting pectinmethylesterase activity in cucumber fruit [thesis]. Oregon(USA): Oregon State University.

Wiander B, Ryhanen E-L. 2005. Laboratory and large-scale fermentation of white cabbage into sauerkraut and 
sauerkraut juice by using starters in combination with mineral salt with a low $\mathrm{NaCl}$ content. Eur Food Res Technol. 220(2):191-195. doi:10.1007/s00217-0041080-5

Yuliana N, Nurdjanah S, Oktarini ZH. 2010. Some biochemical and total lactic acid bacteria changes during natural fermentation of the purple sweet potatoes (Ipomea batatas L) pickle. Work paper. International Seminar on Horticulture to Support Food Security, June 2010. Bandar Lampung (ID): p B209B214.

Yuliana N, Nurdjanah S. 2009. Sensori pikel ubi jalar ungu yang difermentasi spontan pada beberapa tingkat konsentrasi garam. [Sensory properties of spontaneously fermented purple sweet potato pickle at several levels of salt concentrations]. J Teknologi \& Industri Hasil Pertanian. 14(2):119-126.

Zdolec N, Hadziosmanovic M, Kozacinski L, Cvrtila Z, Filipovic I, Skrivanko M, Leskovar K. 2008. Microbial and physicochemical succession in fermented sausages produced with bacteriocinogenic culture of Lactobacillus sakei and semi-purified bacteriocin mesenterocin. Meat Sci. 80(2):480-487. doi:10.1016/j.meatsci.2008.01.012. 